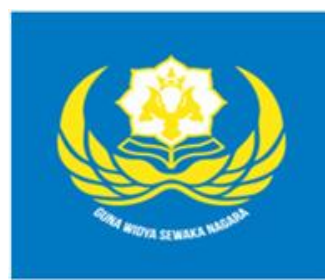

\author{
Linguistic Community Services Journal | Vol. 2, No. 1, 2021 \\ P-ISSN: 2406-9019| E-ISSN: 2443-0668 \\ Available online at \\ https://www.ejournal.warmadewa.ac.id/index.php/licosjournal \\ DOI: https://doi.org/10.22225/licosjournal.v2i1.3174 14-19
}

\title{
LANGUAGE DOCUMENTATION ON LOCAL CULINARY OF OA- CUSSE AMBENO, TIMOR LESTE
}

\author{
I Gusti Ayu Agung Dian Susanthi, Mirsa Umiyati \\ Universitas Warmadewa, Denpasar, Bali-Indonesia \\ gungdian03@gmail.com
}

\begin{abstract}
Abstrak
Kuliner Tradisional merupakan salah satu representasi dari suatu masyarakat yang menjadi identitas budaya. Dengan hadirnya kuliner tradisional tersebut, dapat menjadi suatu sarana dalam mengenalkan kehidupan sosial, budaya dan wisata. Sama halnya dengan negara lain, Timor Leste kaya akan masakan khususnya kuliner tradisional yang memiliki peran besar dalam melestarikan kehidupan masyarakatnya. Pada dasarnya pangan semata-mata tidak hanya berfokus pada konsumsi namun juga meningkatkan citra masyarakat dan memberitahukan kondisi masyarakatnya. Dalam hal ini Magister Ilmu Linguistik Universitas Warmadewa berkolaborasi dengan Escolla Tècnica Vocacional Publico De Palaban, PanteMacassar, Oa-Cusse Ambeno, Timor Leste yang melalui kegiatan Pengabdian kepada masyarakat bertaraf internasional ini mengadakan sosialisasi berupa pelestarian kuliner tradisional Timor Leste dengan menghadirkan masyarakat khususnya generasi muda untuk diperkenalkannya alat, bahan serta prosedur pembuatan kuliner tradisional tersebut dan relasinya dengan kelinguistikan yang berupa kosa kata. Penelitian ini menggunakan jenis penelitian studi kasus untuk mendapatkan hasil yang maksimal. Hasil dari pengabdian ini menyatakan bahwa masyarakat khususnya generasi muda dapat mengikuti sosialisasi dengan baik dan paham mengenai prosedur pembuatan kuliner tradisional serta mampu menyebutkan nama dari jenis makanan tersebut dan menjabarkan setiap prosedurnya.
\end{abstract}

Kata Kunci : Linguistik Kuliner; Kuliner Tradisional; Tmor Leste.

\begin{abstract}
Traditional culinary is a representation of a society that becomes a cultural identity. With the presence of these traditional culinary delights, it can be a means of introducing social, cultural and tourism life. As with other countries, Timor Leste is rich in cuisine, especially traditional culinary delights that have a big role in preserving the lives of its people. Basically, food does not only focus on consumption but also enhances the image of society and informs the condition of the people. In this case, the Master of Linguistics at Warmadewa University collaborates with Escolla Tècnica Vocacional Publico De Palaban, PanteMacassar, Oa-Cusse Ambeno, Timor Leste which through this international community service activity held a socialization in the form of preservation of traditional Timorese culinary by presenting the community, especially the generation young people for the introduction of tools, materials and procedures for making traditional culinary delights and their relation to linguistics in the form of vocabulary. This study shows the interest of the
\end{abstract}


younger generation in their efforts to preserve traditional culinary delights. This research uses a case study research type to get maximum results. The results of this service state that the community, especially the younger generation, can follow the socialization well and understand the procedures for making traditional culinary delights and are able to name the types of food and describe each procedure.

Keywords: Culinary Linguistics; Traditional Culinary; Timor Leste.

\section{INTRODUCTION}

In general and specifically language has an important role in every aspect. Language is the most effective tool to convey the ideas that are in the mind. In this case, it can be said that language has a very important role in human life because with language, humans can communicate with each other orally or in writing. Language is the most effective tool for conveying ideas places in mind. In this case, it can be said that language has a very important role in human life because with language, humans can communicate with each other orally or in writing. Basically, language has a specific science, namely linguistics. Linguistics is the scientific study of human language (Victoria, 2000). Linguistics is divided into several subcategories, one of them is applied linguistics. It is a science that applies research results in the field of linguistics for practical purposes. Applied linguistics is the academic field which connects knowledge about language to decision making in the real world. Generally speaking, the role of applied linguists is to make insights drawn from areas of language study relevant to such decision-making. In this sense applied linguistics mediates between theory and practice (James, 2011). One of the benefits of using applied linguistic theory is to solve practical problems that have a correlation with language.

Applied linguistics is divided into several sections such as cognitive linguistics, computational linguistics, forensic linguistics, language acquisition, language assessment, language development, language education, linguistic prescription, linguistic anthropology, neurolinguistics, psycholinguistics, culinary linguistics and others. A research between culinary and language is research that is arguably still new to researchers. This theory emphasizes the application of existing language to culinary. Furthermore, food consumption and language use often characterize settings, speech events, space, social activity, identity and belief. These aspects are perceived differently by different cultures and are projected onto their languages in which culinary linguistics can take part (Dohra, 2018). Culinary linguistics is defined as the qualitative study of a language's foodways and food through the paradigms of linguistics. This aims to study the culinary world through the language one is existing (Jabonillo, 2016). In preserving traditional culinary, there are several ways to do. Most people maintain traditional foods and drinks by maintaining their names, ingredients, cooking methods, presentation methods and packaging (R.Aj. Atrinawati, 2019). While Gerhardt (2013) defines culinary linguistics implicitly as a study of food from a linguistic perspective. On the other hand, the richness of Timor Leste traditional culinary can potentially become a tourist attraction (Elizabeth Barreto Araujo, 2016)

One of the objects that can be researched using this theory is traditional culinaries that are present as a representation of each society. The main function of food is not only consumed but also has a connection between humans and God, human beings, and human with nature as well as cultures that are inherent in its presentation. A role of the culture is valuable in making traditional culinary such as creativity, a touch of art, tradition and taste. The higher the culture of a community (Didin, 2018). While Guererro (2010) states a product frequently consumed or associated with specific celebrations and/or seasons, normally transmitted from one generation to another, made accurately in a specific way according to 
the gastronomic heritage, with little or no processing/manipulation, distinguished and known because of its sensory properties and associated with a certain local area, region or country.

The importance of knowing traditional culinary names, tools, ingredients and presentation methods are the right steps in preserving it. On the other hand, it is better if the philosophy or meaning implied in each of its making should be known so that people continue to follow and implement what has existed over the generation. Furthermore, with linguistic culinary is able to dissect the elements that exist in culinary such as philosophy, ingredients, tools, serving methods, and most importantly language documentation of traditional culinary. This Community Service activity is designed to obtain mandatory and additional outputs. The mandatory output of this activity is a scientific publication in the scientific journal with ISSN. Meanwhile, the mandatory output is in the form of increasing understanding of the people of Timor Leste, especially the younger generation related to traditional culinary, in the final evaluation in the form of a pocket book listing traditional culinary names, tools, ingredients and serving procedures. In this way, the mandatory output in the understanding and ability of partners will be well known.

\section{RESEARCH METHOD}

This research is designed with a qualitative research approach. It is a form of community service program. There are several steps taken in this activity. In the observation stage, the preliminary research data collection which is used as a basis for conducting research is carried out by means of in-depth-interviews so that the participants produce answers in the form of narratives from the research object. The object of this research is the people of Timor Leste, especially the younger generation who placed in Oa-Cusse Ambeno. The in-depthinterview stage is carried out using a media in the form of Zoom. Descriptive techniques are used to analyze the results of the research after the data is collected. The results of this research revealed that some of the participants do not know the name of the culinary, the tools and ingredients that are used and the process of serving it.

\section{RESULTS AND DISCUSSION}

\section{Training to Increase Community Knowledge related to Traditional Culinary}

Based on the mission and objective that become a reference in the development of Warmadewa University, namely to carry out community service based on research and in accordance with the needs of the community, in this case an international community service program is held between Warmadewa University in Collaboration With Escolla Tècnica Vocacional Publico De Palaban, Pante-Macassar, Oa-Cusse Ambeno, Timor Leste in order to improve the understanding of the younger generation related to traditional culinary.

\section{Participant Profil}

the Community Service Program was attended by various groups which are presented in the following table.

\begin{tabular}{|l|c|c|c|}
\hline \multirow{2}{*}{ Participant } & \multicolumn{2}{c|}{ Gender } & Total \\
\cline { 2 - 3 } & Male & Female & \\
\hline Third Grade Junior High & 100 & 126 & 226 \\
School Students & & 3 & 15 \\
\hline Teachers & 12 & 2 & 12 \\
\hline Guests & 10 & $\mathbf{2 5 3}$ \\
\hline \multicolumn{2}{|c|}{ Total } \\
\hline
\end{tabular}

Table 1. Participant Profil 
Based on the table above, it is known that there are three groups of participants who attended the community service program with a total of 253 people. Third Grade Junior High School Students are 226 people, of which 100 male and 126 female. Teachers as many as 15 , where there are 12 male and 3 female. Meanwhile, the guests include The Secretary of Tourism, Director of Tourism, Director of Education, The Indonesian Embassy of Timor Leste in Oecusse and the other teachers from other schools, totaling 12 people, of which 10 are male and 2 female.
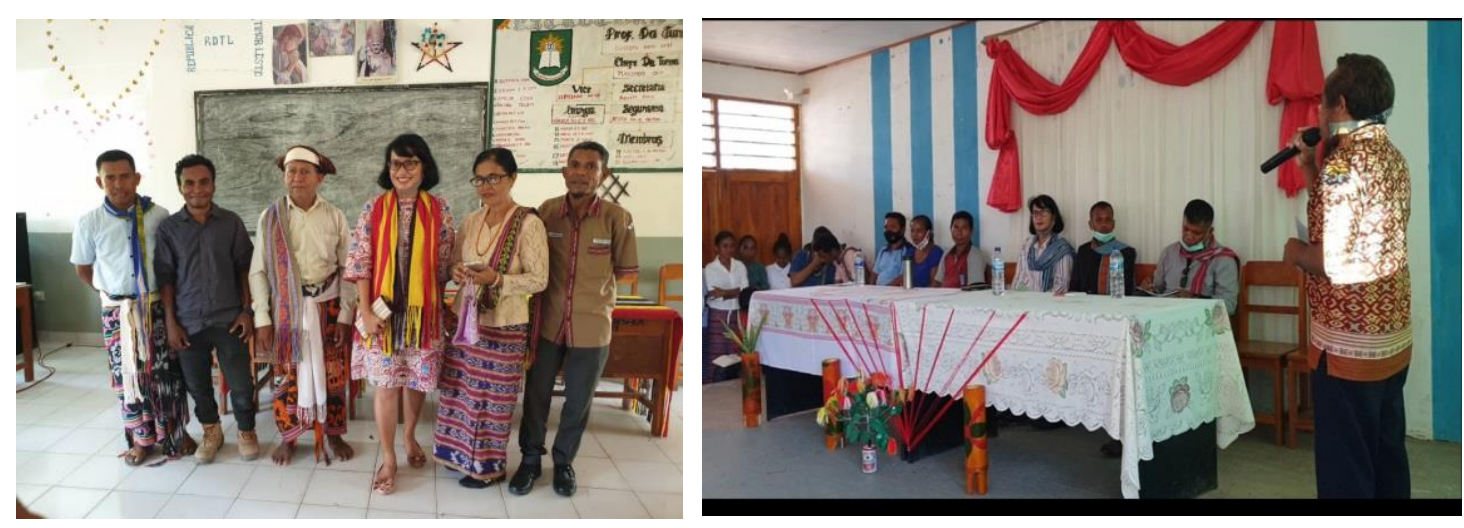

Picture 1. The Secretary of Tourism, Director of Tourism, Director of Education, The Indonesian Embassy of Timor Leste in Oecusse and the other teachers from other schools
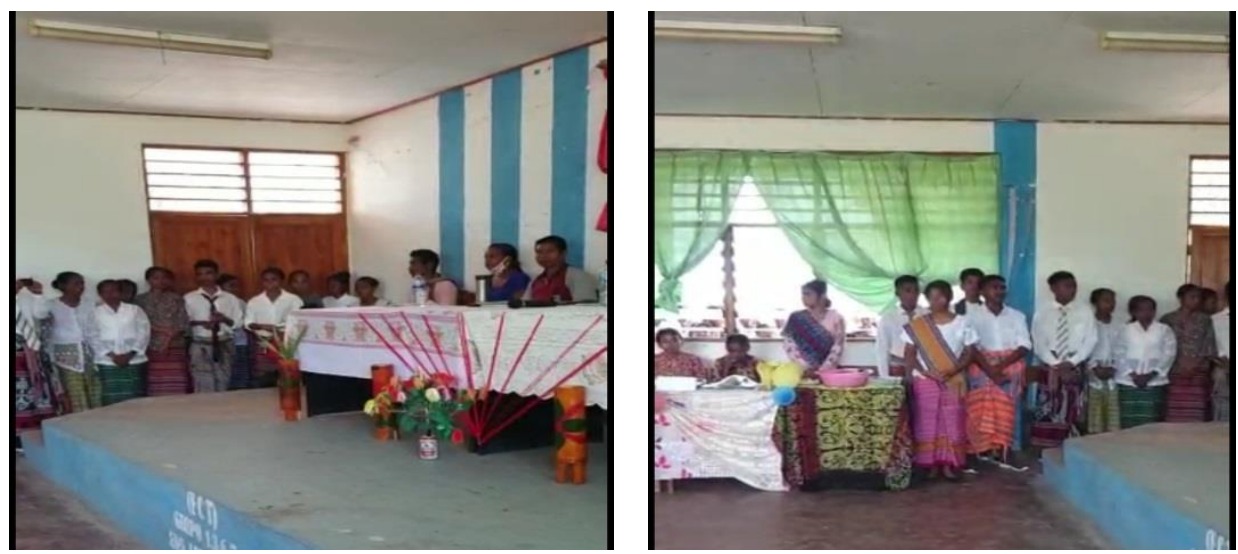

Picture 2. Students and Teacher attend the program

In carrying out the health protocol established by the government, this activity is carried out online with the media in the form of Zoom as an intermediary between Warmadewa University and Escolla Tècnica Vocacional Publico De Palaban, PanteMacassar, Oa-Cusse Ambeno, Timor Leste in order to improve the understanding of the younger generation related to traditional culinary which is presented in the following documentation 

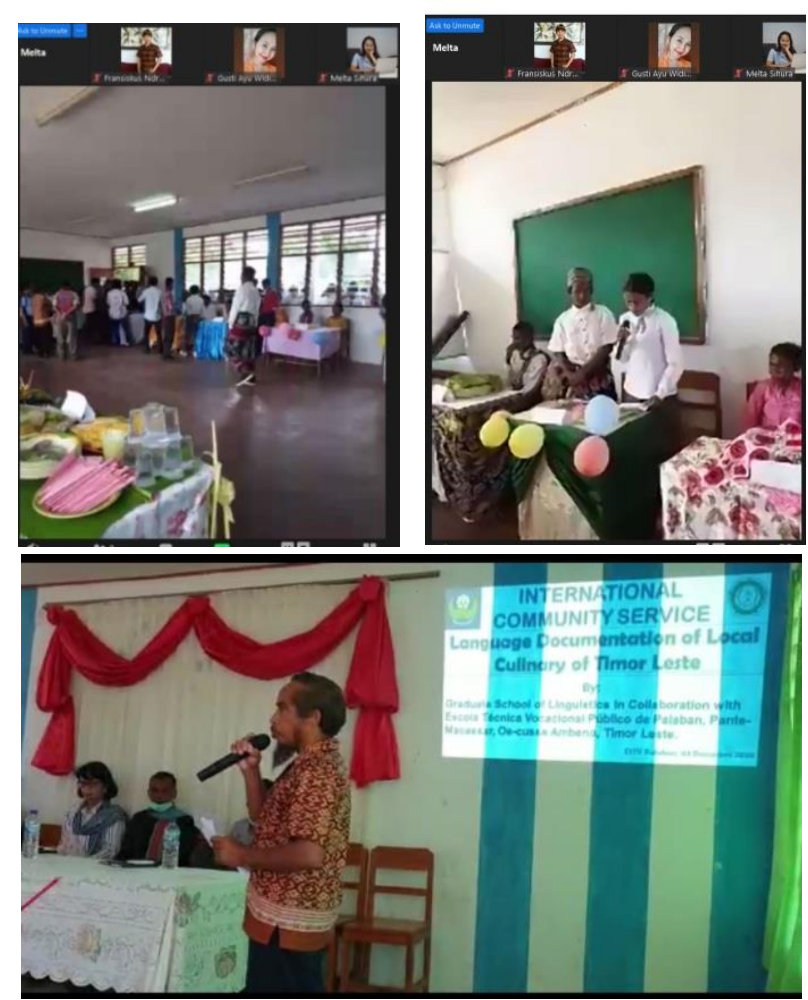

Picture 3. International Community Services via Zoom

\section{Improving Community Understanding of Traditional Culinary}

In preserving traditional culinary of Timor Leste, people should know the names, tools, ingredients and methods of presentation in order to documenting the language. It has a very diverse local culinary. in this case it can present the culture that is present in the community because many aspects interact over food (socialization, group identity, etc.) (Polly, 2014). Basically, food is only for consumption, but with the presence of human language, people can find out how the food is made up to the presentation stage. On the other hand, it also adds to knowledge, especially the lexicon which is language documentation.

\begin{tabular}{|c|l|}
\hline Lexicon & \multicolumn{1}{|c|}{ Description } \\
\hline $\begin{array}{l}\text { Puding Ubi Jalar } \\
\text { Source: Internet }\end{array}$ & $\begin{array}{l}\text { Puding Ubi Jalar is made with the main ingredient, namely } \\
\text { cassava mixed with jelly, coconut milk and eggs then put } \\
\text { into a food container. }\end{array}$ \\
\hline Tuak Tradisional & $\begin{array}{l}\text { Traditional Tuak is made with yeast which is fermented for } \\
\text { several days to get an alcohol content. This drink is in great } \\
\text { demand by the public when special activities such as parties } \\
\text { are held }\end{array}$ \\
\hline
\end{tabular}




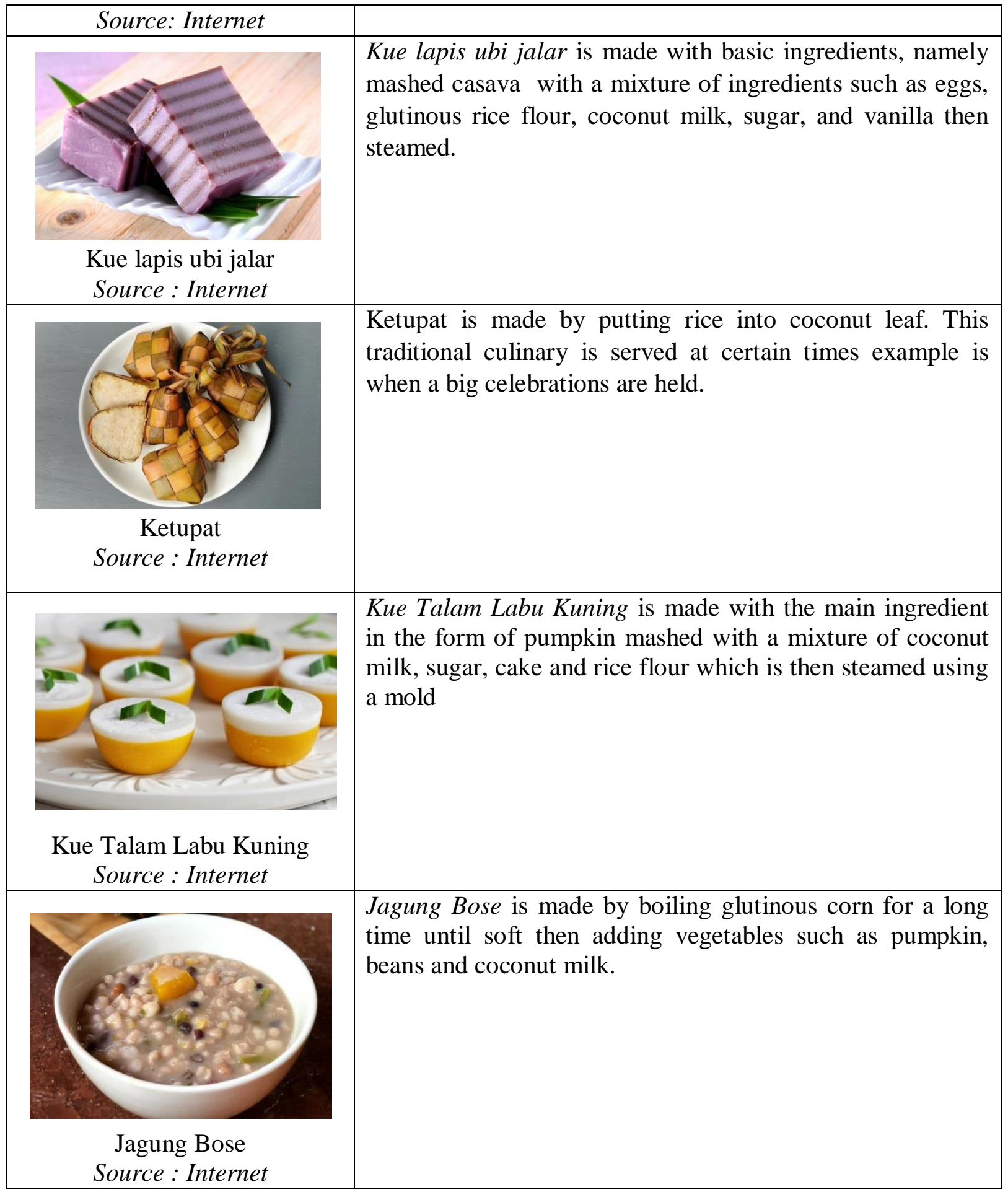

Table 2. Language Documentation of Local Culinary

These are several Community Service activities held through Zoom, namely:

1. Introducing the name of Traditional Culinary to the younger generation to increase knowledge in the form of vocabulary (lexicon) or what is commonly referred to as language documentation

2. Introducing the tools and materials used to process food

3. Explain the processing procedure up to the presentation stage 


\section{CONCLUSION AND SUGGESTION}

The results of the Community Service activities went according to the target and showed that the majority of the younger generation did not know the traditional culinary of Timor Leste. So, in this activity held by Master of Linguistics of Warmadewa University in Collaboration with Escolla Tècnica Vocacional Publico De Palaban, Pante-Macassar, Oa-Cusse Ambeno had the opportunity to provide a solution in the form of a Language Documentation to provide knowledge in the form of culinary names, tools and ingredients as well as presentation methods. Basically, this activity seeks to revitalize Timor Leste's culture in the form of traditional culinary.

\section{REFERENCES}

Araujo, E. B. (2016). Pengembangan Kuliner Lokal Sebagai Daya Tarik Wisata di Dili, Timor Leste. JUMPA, 3(1), 15-27.

Atrinawati, R. A. (2019). Javanese Culture Maintenance by Keeping Traditional Javanese Food and Beverage Name in Tegal Regency Traditional Culinary Tourism. Journal of Cultural, Literary, and Linguistic Studies, 3(2), 41-46.

Fitrisia, D., Sibarani, R., Mulyadi, \& Ritonga, M. U. (2018). Traditional Food in the Perspective of Culinary Linguistics. International Journal of Multidisciplinary Research and Development, 5(2), 24-27.

Gerhardt, C., Frobenius, M., \& Ley, S. (2013). Culture and Language Use Studies in Anthropological Linguistics CLU-SAL. In Culinary Linguistics: The Chef's Special. Amsterdam: John Benjamins Publishing Company.

Guerrero, L., Claret, A., \& Verbeke. (2010). Perception of Traditional Food Products in Six European Regions Using Free Word Association. Jurnal Food Quality and Preference, 21(2), 225-233.

Jabonillo, J. P. B.-A. (2016). Pagkaong Binol-Anon: A Preliminary Research on Boholano Culinary Linguistics. In Sciences-New York. Quezon: University of the Philippines Diliman.

Simpson, J. (2011). Technology and Language Learning at Byu. In CALICO Journal (Vol. 1, Issue 3). Routledge.

Syarifuddin, D., Noor, C. M., \& Rohendi, A. (2018). Memaknai Kuliner Lokal Sebagai Daya Tarik Wisaya. Jurnal Abdimas, 1(1), 55-64.

Szatrowski, P. E. (2014). Language and Food: Verbal and Nonverbal Experiences. John Benjamins Publishing Company.

Victoria, Fromkin, \& Curtiss, S. (2000). Linguistics An Introduction to Linguistic Theory. Blacwell. 